\title{
Spectral Measurements of the Global Radiation by an Automatic Photoelectric Method (I)
}

\author{
-Preliminary Report - \\ by \\ K. Murai \\ Meteorological Research Institute, Tokyo
}

(Received April 9, 1962)

\begin{abstract}
For the spectral measurement of the global radiation, we designed an instrument using an interference filter, a multiplier phototube and a diffuser. Since the diffuser plays a very important role in maintaining the directional cosine law, we constructed it taking the utmost precaution. As the results of the experimental tests, it was shown that the integrating sphere attached to the opaque plastic plate at the exit hole of the light, represents the best characteristics of the diffusibility. The deviation of the characteristic curve from the cosine curve is less that $5 \%$ at the incident angles from 0 to $70 \mathrm{deg}$.

We picked out five narrow wave length intervals from near-ultra violet and visible regions. As detectors, five photomultipliers were used and their output photocurrents are recorded simultaneously.

The response of the instrument is very sensitive to the variation of the high tension power supply and even a small fluctuation is able to cause a significant error in the recorder.

Calibration was carried out by means of the standard lamp several times a day.
\end{abstract}

\section{Introduction}

The amount of the global radiation has long been observed regularly at many stations in the world, as one of the fundamental meteorological elements. It is an important quantity not only as the source of the atmospheric dynamics, but also for its many effects on the human lives. Since this quantity varies violently depending on the conditions of cloudiness and atmospheric turbidity, it is an important problem for us to investigate the relation between the global radiation and the cloudiness, the turbidity or such atmospheric conditions. B. HAURwITz (1945) obtained some results by the statistical investigations on this problem, using the records of the Eppley pyrheliometer at Blue Hill Meteorogical Observatory, during the period of 11-years 1933-1943, and represented the global radiation as a function of air mass, taking cloudiness and cloud density as the parameter.

Recently, the spectral measurement of the global radiation is demanded from 
several kinds of fields, and it is interesting to investigate the dependency of the monochromatic global radiation on the cloudiness, the cloud density and the turbidity, etc.

In 1951, R. SchulzE observed the monochromatic global radiation using the filters and the photocells, in the spectral regions of near ultraviolet and visible. Because of the low sensitivity of the photocell, he could not measure the amount of monochromatric global radiation in sufficiently small wavelength interval and at the time of low sun. Recent developments of the multiplier phototube have almost solved the above-mentioned difficulty in sensitivity. Y.T. Sinvonen et al. (1958) measured the global radiation with the spectrometer and $\mathrm{PbS}$ cell, and got the spectral distribution of them.

In this paper, we describe the instrument using the multiplier phototube as the detector, and using the interference filter for the selection of wavelength interval.

\section{Instrumentation}

The appearance and the construction of the instrument are shown in Figs. 1 and 2. The components of the receiving parts of the instrument are the integrating sphere as diffuser, the interference filter and the multiplier phototube as detector.

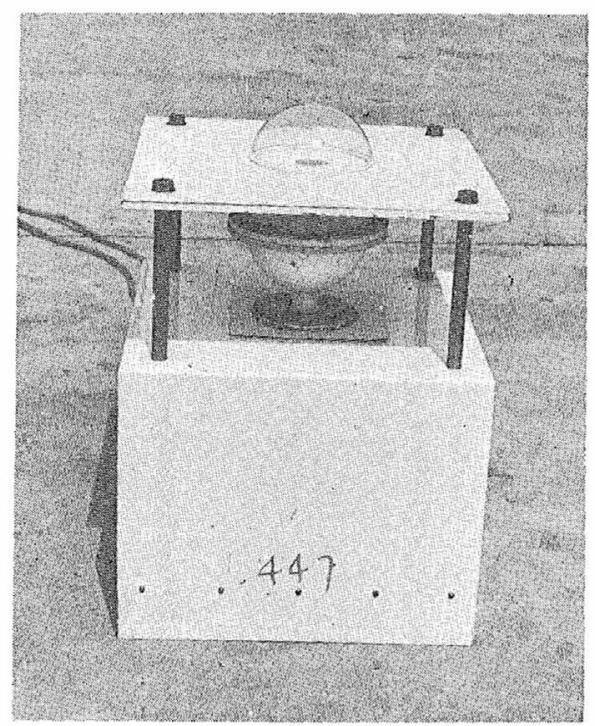

Fig. 1. Aspect of the instrument except the part of power supply and recorder.

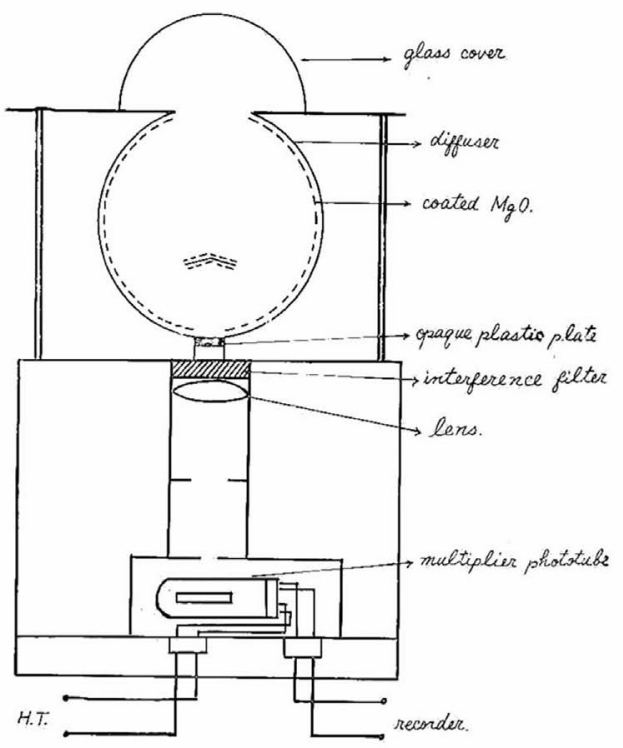

Fig. 2. Diagram of the instrument. Diameter of the diffuser is $10 \mathrm{~cm}$.

\section{a) Diffuser}

In the laboratory, we usually employ the integrating sphere as the best diffuser of the incident light, so we applied it to the measurement of the global radiation. It is a sphere which has two holes as the entrance and the exit of light respectively, and on its inner surface the magnesium oxide is bound by the white paint so as to 
reflect the light diffusely at all points. The theory of the integrating sphere is described by O. E. Miller and SANT (1958) in detail. Since the intensity at the exit of the sphere is to be proportional to the cosine of incident angle of the light at the entrance, that is the receiving surface of light, we took great precaution for the coating of magnesium oxide and moreover attached an opaque plastic plate at the exit of the light.

The results of the experimental tests of the diffusibility of the sphere are shown in Fig. 3, in which the curve $\mathrm{A}$ is the characteristics of the integrating sphere only, the curve $B$ is that of the one attached to the opaque plastic plate and $\mathrm{C}$ is the theoretical curve of cosine law. By the attachment of the opaque plastic plate, the incompleteness of the diffusibility of the sphere is improved considerably, and the deviation of the curve $\mathrm{B}$ from cosine curve is less than $5 \%$ in the greater part of the angle of incidence.

It is, however, more than $15 \%$ at a very large angle of incidence (>80 deg.).

Since the diffusibility of the sphere is considered to become worse after a long-term operation, it is necessary to perform the coating of the magnesium oxide in the time intervals of a few months.

\section{terval \\ b) Selection of the wavelength in-}

We selected five wavelength intervals in the region of near ultraviolet and visible, i.e., 381, 447, 578, 661 and 766

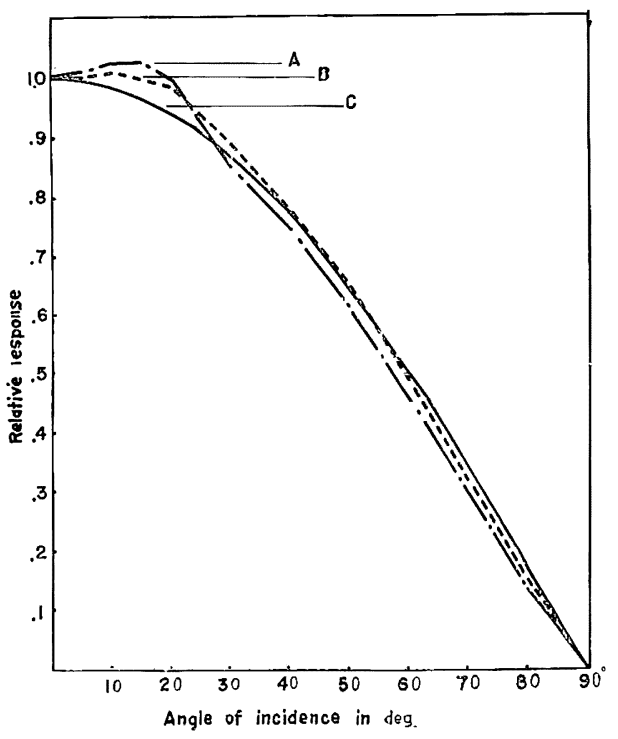

Fig. 3. Directional characteristics of diffuser. Curve A : integrating sphere only, $\mathrm{B}$ : integrating sphere attached to the opaque plate at the exit hole and $\mathrm{C}$ : theoretical curve of cosine. For the optical experiment, we used a circular bench of about $1 \mathrm{~m}$ radius, and light source moves around the instrument, that is settled at the bench so that the optical axis is holizontal.

$\mathrm{m} \mu$. We used the interference filters of the Lange Type, and their transmission characteristics are shown in Fig. 4. The maximum transmission at the center of each wavelength intervals is approximately 30 per cent, and the half widths are respectively about $10 \mathrm{~m} \mu$, except for the wavelength interval of $766 \mathrm{~m} \mu$, in which it is more than $40 \mathrm{~m} \mu$.

As shown in Fig. 2, only the light which is transmitted through perpendicularly to the plane of the filter, is focused at the cathode of the detector by lens and diaphragms.

\section{c) Detector and high tension supply}

In order to get the high sensitivity, we employed the multiplier phototube as detector. Then, we are able to measure a very small amount of the global radiation, e. g. at the time of very low sun or when a dense cloud overcasts the sky. 


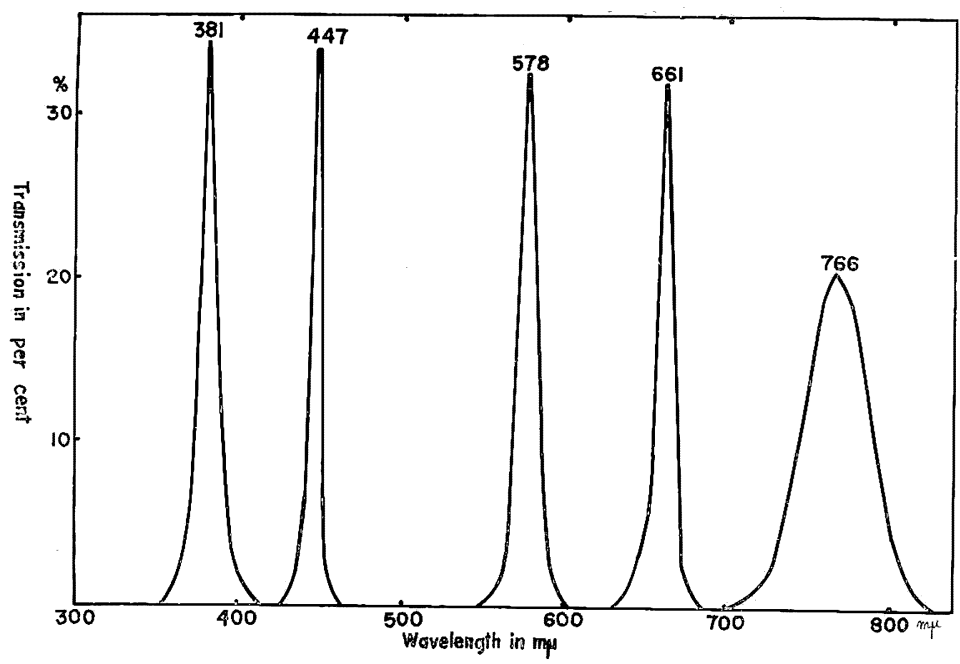

Fig. 4. Transmission of interference filter.

The following types of multiplier phototubes are used to detect the radiation of each wavelength interval, that is, RCA $1 \mathrm{P} 28$ for $381 \mathrm{~m} \mu$, RCA 931A for 447, 578 and $661 \mathrm{~m} \mu$ and Toshiba 7305 (equivalent to RCA IP 22) for $766 \mathrm{~m} \mu$.

The output current of the multiplier phototube varies sensitively, according to the little changes in the value of supplied high tension. The characteristic curve of the output current to the supplied high tension is shown in Fig. 5.

The value of the supplied high tension is controlled discontinuously (12 steps) between 200 and 1,200 Volt, so as to make the output current of the detector less

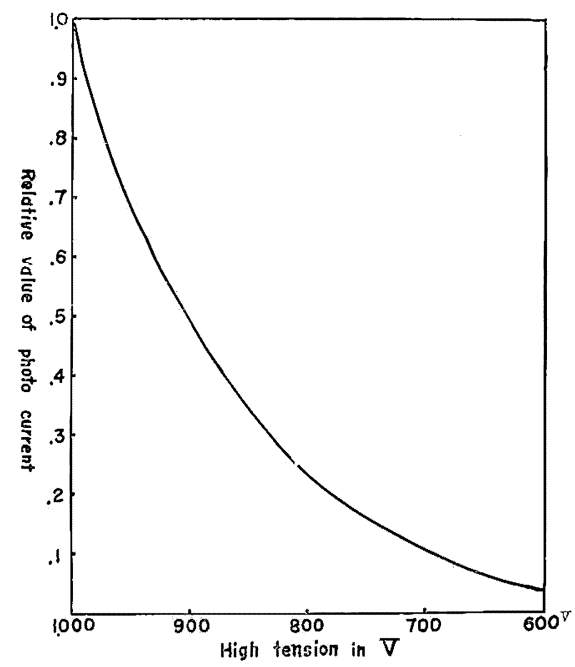

Fig. 5. Characteristics of out put current to high tension power supply.

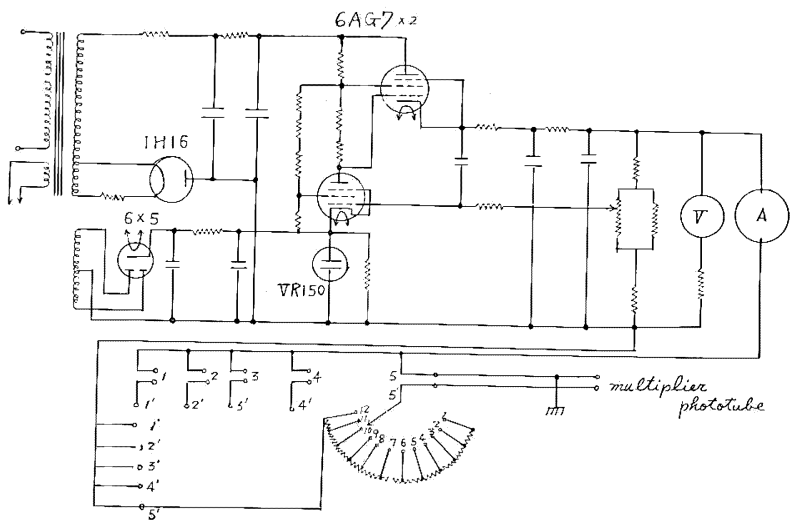

Fig. 6. Circuit diagram of high tension power supply. 
than $20 \mu \mathrm{A}$. Although the output voltage of the supply is stabilized by the electronic circuit as shown in Fig. 6, there is about 0.1 or 0.2 per cent of the short period fluctuation and the gradual change of the output voltage in a day is about $1 \%$.

According to the characteristics of the photocurrent, which is shown in Fig. 5, the fluctuation of the output current due to the short-period random change of the high tension supply increases as the value of the high tension increases. In case of the measurement, the supplied tension is less than 800 Volts at the time of high sun, but at the time of low sun, more than 1.000 Volts of high tension is supplied. Accordingly, in the latter case the accuracy of the measurement is worse than the former.

The gradual variation of the response of the instrument in a day is rather remarkable, but the recorded value of the output currents is reduced to the standard situation by the calibration that is performed several times a day with the standard tungsten lamp.

\section{Measurements and errors}

At the time of measurements, the output currents of five instruments are feeded to the six-component electronic recorder, and each one of them is dotted every 30 seconds.

Just before the exposure of the instruments to the radiation, their responses are calibrated by the standard lamp, and then the calibrations are performed at intervals of one or two hours.

The atmospheric conditions are observed once in every hour; the observed elements are cloudiness, type of cloud, and visibility.

A sample of the record is shown in Fig. 7.

Errors in measurements principally arose from the fluctuation of the supplied high tension and the deviations of the directional characteristics of the diffusibility of the integrating sphere from cosine law.

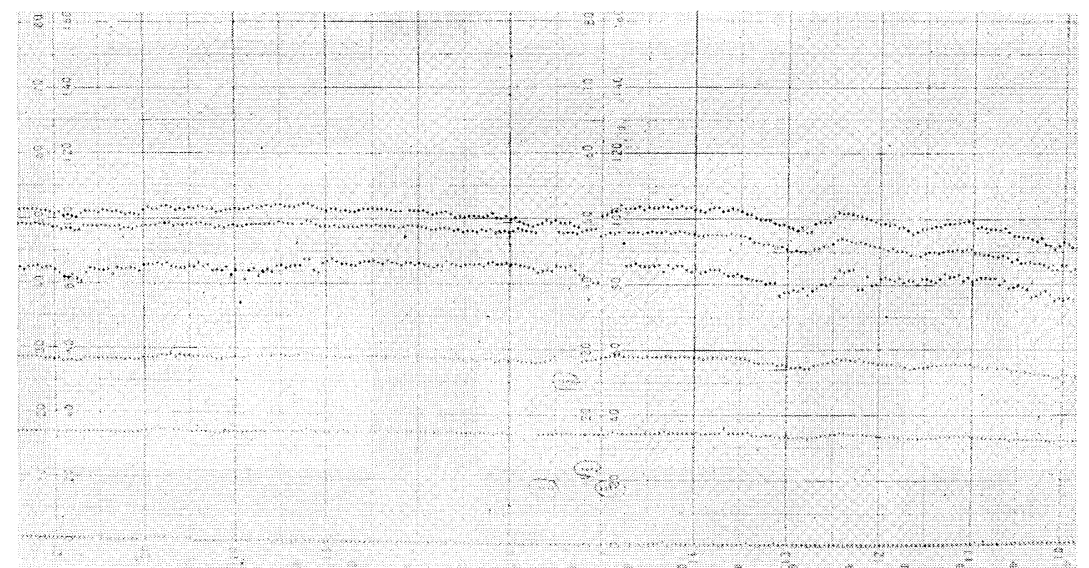

Fig. 7. Records of out put currents of multiplier phototubes. They are records of a clear day, and of periods of two hours containing the time of southing of the sun in the middle of the recording paper. Marked dots indicate the values of the calibration. 
As described in the preceding section, errors due to the gradual change of the supplied high tension are removed by calibration, but those due to the short-period random fluctuation of the high tension cannot be removed. It will amount to several per cent at 1.100 Volts of high tension, and a few per cent at 1.000 Volts.

In case of the measurements, the supplied tension is usually less than 900 Volts, so that errors coming from the electrical disturbances are less than a few per cent. It is not, however, the case when the intensity of the incident radiation is very small; i. e. when the altitude of the sun is very low or when the sky is covered with dense cloud, the value of the supplied high tension is more than 1.000 Volts.

As shown in the previous section, the deviation of the characteristics of the diffuser from the cosine curve is larger at the horizontal and the normal incidence than the intermediate angle of incidence. The ratio of the area of the sky, which is subtended by the angle from $0^{\circ}$ to $10^{\circ}$ of the elevation covering the whole azimuth, to the whole hemisphere is about $17 \%$, and that subtended by the zenith distance from $0^{\circ}$ to $10^{\circ}$ is about $6 \%$.

The error due to the diffuser, therefore, is considerably large for the horizontal incidence of radiation. Since the ratio of the intensity of the diffused sky radiation to the direct solar radiation is larger in the short wavelength than the long wavelength, at the time of very low sun, this error is smaller in the ultraviolet region than in the visible.

The efficiency of the diffusibility of the magnesium oxide, which is bound on the inner surface of the diffusing sphere, will deteriorate after long periods of exposure for measurement. Practically, we can not detect any remarkable deterioration in a few months, and then we smoked some new powder of magnesium oxide after the exposure for two or three months, examining the diffusibility by the laboratory experiment.

By the analysis of the records, we intend to investigate the spectral effects of the aerosol, cloud particles and absorbing matter, to the global radiation. We are now observing in the wavelength intervals not affected by the absorption, and in future, we shall extend our studies to the intervals with remarkable effects of absorption.

\section{Summary}

We constructed an instrument for the spectral measurements of the global radiation, using the integrating sphere, the interference filter and the multiplier phototube.

The diffusibility of the integrating sphere is improved by the attachment of an opaque plate, and the deviation from the cosine law is less than $5 \%$, except for the nearly horizontal incidence.

As detector, we employed the multiplier phototube so as to be able to detect the radiation of very weak intensity. Although the high tension supplied to the phototube is electronically stabilized, the fluctuation of the output voltage is the principal source of errors in the record, especially at the value of more than 1.000 Volts.

Since the long-term stability of the diffusibility of the spherical diffuser is not 
considered to be good enough, it is necessary to renew the coating of magnesium oxide after two or three months of operation.

The response of the instrument is calibrated by the standard tungsten lamp several times a day and the directional characteristics of the diffuser is examined by the laboratory experiment.

Acknowledgements__ The author wishes to express his cordial thanks to Dr. K. Sekinara for his kind advice and help, and also to Mr. Y. Ogawa and Miss. R. MukaI for their earnest assistance in the experiment.

\section{References}

HAURWLTZ, B. 1945 : Insolation in relation to cloudiness and cloud density. J. Met., 2, 154-166. MilLer, O. E. and A. J. SANT, 1958: Incomplete integrating sphere. J. O.S. A. 48, 829-831.

Sonulze, R. 1951: Zur Abhängigkeit des Globalstrahlenspektrums von der Sonnenheit. Ann. der Met., 1, 176-182.

Sihvonen, Y. T., R. F. Aajkowski and W. Stater, 1958: A presentations of solar radiation data obtained by a spectroheliometer. Solar Energy, The Journal of Solar Energy Science and Engineering, 2, No. 1, 21-25.

\section{水平面日射量の波長別測定について}

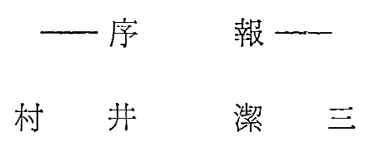

水面日射量を波長別飞测定するために，幵渉フイルタ一，光電子增倍管特よび光の拡教装置を組合わせ た装置を試作した。受光面が種々の入射角からの入射光に対して完全飞 cosine 法則飞従うようにするため そ拡散装置は非常飞重要で，試作当つて最も注意を払つた点である。拡散装置としては，一般飞室内実 験で用いられている積分球を用い，さらに，その光の出口飞半透明なプラチックの板を取付けることによ り，方向に対する罡性はかなり改善されている。入射有 $0^{\circ} \sim 70^{\circ}$ の籁四では， cosine 法則からのずれは $5 \%$ 以下である。

測䇥する波長は，干沙フイルターねよつて近紫外招よび可視領域から5つの波長を選び出し，㭘知器と しては，5個の光電子増倍管を用い，その光電流を電子管式記録計により遭続記録している。光電流は， 供給する高正電源の変動に対して敏感であるので，1 日の测定の間飞数回標準電球による感知の検定を行 なつている。 